\title{
Efektivitas Mediasi dalam Penyelesaian Perkara Perceraian di Pengadilan Agama Menurut Peraturan Mahkamah Agung (PERMA) No. 1 Tahun 2016
}

\author{
Ria Zaitullah \\ (Institut Dirosat Islamiyah Al-Amien (IDIA) Prenduan, email: \\ ria.zaitullah@gmail.com)
}

\begin{abstract}
Abstrak:
Artikel ini mengkaji tentang efektivitas mediasi dalam penyelesaian perkara perceraian di Pengadilan Agama menurut Peraturan Mahkamah Agung No.1 Tahun 2016 , sebagai upaya yang real yang dilakukan oleh Pengadilan dalam mempertahankan keutuhan rumah tangga. Proses mediasi yang dilakukan oleh Pengadilan Agama merupakan sebuah upaya dalam penyelesaian sengketa melalui proses perundingan atau mufakat para pihak dengan dibantu oleh mediator yang tidak memiliki kewenangaan dalam memutus atau memaksakan sebuah penyelesaian. Kajian ini merupakan kajian kualitatif, dalam kajian ini ditemukan bahwa dalam realitas yang ada di masyarkat pemberlakuan mediasi masih kurang efektif dalam menyelesaikan perkara, terbukti dari sedikitnya perkara yang berhasil diselesaikan dengan mediasi. Penyebab paling utama dalam hal ini adalah kurangnya kesadaran, egoisme dan tidak adanya kemauan untuk berdamai. Dualisme fungsi mediator yang juga berperan sebagai Hakim memberikan pengaruh bagi mediasi yang dilakukannya. Diperlukan adanya mediator non Hakim ataupun mediator bersertifikat yang lebih berpengalaman untuk lebih meningkatkan keberhasilan proses mediasi. (This article examines the effectiveness of mediation in the resolution of divorce cases in the Religious Courts according to the Supreme Court Regulation No. 1 of 2016, as a real effort by the Court in maintaining the integrity of the household. The mediation process carried out by the Religious Courts is an attempt to settle disputes through a negotiation process or agreement of the parties with the assistance of mediators who do not have the
\end{abstract}


Efektivitas Mediasi dalam Penyelesaian Perkara Perceraian di Pengadilan Agama Menurut Peraturan Mahkamah Agung (PERMA) No. 1 Tahun 2016

authority to decide or force a settlement. This study is a qualitative study, in this study it was found that in reality in the community the application of mediation is still less effective in resolving cases, as evidenced by the small number of cases successfully resolved by mediation. The main reasons for this are lack of awareness, selfishness and lack of willingness to make peace. The dualism of the mediator's function which also serves as the Judge influences the mediation he does. Non Judge mediators or certified experienced mediators are needed to further enhance the success of the mediation process.)

\section{Kata Kunci:}

Efektivitas, Mediasi, PERMA No.1 Tahun 2016.

\section{Pendahuluan}

Dalam proses perceraian yang terjadi di Pengadilan Agama, kedua belah pihak selaku suami istri harus menjalani proses mediasi yang telah ditetapkan. Dan untuk memudahkan akses masyarakat terhadap keadilan melalui mediasi, Mahkamah Agung telah menerbitkan Hal tersebut disampaikan oleh Wakil Ketua Mahkamah Agung Bidang Non Yudisial Dr. Sunarto, SH., MH yang diwakili oleh Hakim Agung Dr. Nurul Elmiyah, SH.,MH dalam sambutannya pada Seminar Nasional dengan tajuk "Mewujudkan Restorative Justice Dalam Penyelesaian Sengketa Hukum dan Konflik Horizontal di masyarakat Melalui Mediasi Sebagai Alternatif Dispute Resolution". ${ }^{1}$

Mediasi adalah salah satu cara penyelesaian sengketa yang ada di dalam rumah tangga yang berasaskan pada dasar hukum yang terdapat dalam Al-Quran surat Al-Nisa ayat 35 untuk memperoleh penyelesaian yang memuaskan serta berkeadilan. Dalam rangka reformasi birokrasi Mahkamah Agung Republik Indonesia yang berorientasi pada visi terwujudnya badan peradilan Indonesia yang agung, salah satu elemen pendukung adalah Mediasi sebagai instrumen untuk meningkatkan akses masyarakat terhadap keadilan

${ }^{1}$ Hanasthasia Karrenina Kereh, "Penyelesaian Sengketa Melalui Mediasi Di Pengadilan Menurut PERMA No 1 Tahun 2016 Tentang Prosedur Mediasi," Lex Administratum Vol 7, no. 2 (June 2019): 42. 
sekaligus implementasi asas penyelenggaraan peradilan yang sederhana, cepat, dan berbiaya ringan.

Terkait dengan persoalan perceraian, Departemen Agama Republik Indonesia pada tahun 2017-2018 mencatat bahwa terdapat peningkatan data statistik dalam kasus perceraian yaitu pada tahun 2016 terdapat 365.654 kasus, meningkat di tahun 2017 menjadi 374.516 kasus, dan semakin meningkat lagi pada tahun 2018 sebanyak 408.202. ${ }^{2}$ Sebagai contoh kasus mediasi di Pengadilan Agama Bogor tahun 2018 sebanyak 290 perkara dan yang berhasil diselesaikan sebanyak 25 perkara. Di Malang tahun 2018 ,sebanyak 542 perkara dan yang berhasil diselesaikan sebanyak 63 perkara. ${ }^{3}$

Lebih jauh diuraikan bahwa terdapat 13 komponen penyebab perceraian. Beberapa diantaranya disebabkan oleh praktik poligami suami, perselingkuhan, masalah kebutuhan ekonomi, pernikahan dini, perbedaan keyakinan politik antara suami dan istri, serta masalah beda agama dalam ikatan pernikahan. ${ }^{4}$ Dan yang menjadi penyebab utama terjadinya perceraian adalah gagalnya pasangan suami istri dalam membangun komunikasi yang baik antar keduanya, dan dilanjutkan dengan sebab ekonomi dan perselingkuhan.

Pada kasus perceraian sendiri, sebagaimana dikemukakan bahwa ada beberapa isu yang memang sangat terkait pada upaya pemenuhan keadilan bagi perempuan, yaitu mengenai pembagian harta gono-gini, hak talak perempuan dalam masa gugatan perceraian, termasuk didalamnya persoalan pemenuhan nafkah, masa iddah dan proses rujuk pasangan suami istri.

Adapun fokus kajian sebelumnya adalah penyelesaian sengketa perkara perdata melalui litigasi mulai ditinggalkan dan beralih ke Alternative Dispute Resolution/ ADR (Mediasi). Wujud perubahan ini dilakukan dengan menerbitkan Perma No.1 Tahun 2003 yang ditulis oleh Muhammad Saifullah, kemudian pada kajian selanjutnya direvisi melalui Perma No.1 Tahun 2008 tentang Prosedur Mediasi di

2 http;//databoks.katadata.co.id/datapublish/2020/02/20/ramaiRUU-ketahanan-keluarga-berapa-angka-perceraian-di-Indonesia.

3 http:// www.pa-malangkota.go.id/Angka-keberhasilan-MediasiPa-Malang-Tahun-2018

4 Yusdani, Menuju Fiqih Keluarga Progresif (Yogyakarta: Kaukaba Dipantaran, 2015), 79. 
Pengadilan Agama yang ditulis oleh Hery Diansyah. Dan diulas kembali melalui tulisan Siti Musawwamah dengan judul "Integritas Mediasi di Pengadilan Agama". Inilah langkah besar yang dilakukan oleh Pengadilan Agama dalam mengurangi tingkat perceraian yang ada di Indonesia.

\section{Metode Penelitian}

Jenis kajian ini adalah studi pustaka (literature) dengan pendekatan kualitatif. Dan untuk memperoleh data-data yang diperlukan penulis menggunakan metode documenter, untuk mengetahui sejarah perkembangan proses mediasi di Pengadilan Agama yang bermula pada Peraturan Mahkamah Agung (PERMA) Nomor 2 Tahun 2003 tentang prosedur Mediasi di Pengadilan, PERMA ini kemudian diubah menjadi PERMA Nomor 1 Tahun 2008 dan terakhir diubah menjadi PERMA Nomor 1 Tahun 2016.

Dari data -data yang terkumpul dianalisa dengan menggunakan metode Induktif dalam mengambil kesimpulan tentang efektivitas PERMA Nomor 1 Tahun 2016, kemudian metode deduktif untuk mengetahui pengertian mediasi, langkah-langkah dalam proses mediasi, dan efektivitasnya dalam kasus perceraian yang ada di masyarakat.

\section{Kajian Teoritik Mediasi dalam Perkawinan}

Pengertian Perkawinan

Perkawinan menurut hukum Islam adalah pernikahan, yaitu akad yang sangat kuat atau mitsaqan qhalidzan untuk mentatati perintah Allah \& melaksanakannya merupakan ibadah. Perkawinan bertujuan untuk mewujudkan kehidupan rumah tangga yang sakinah, mawaddah dan rahmah. Dan perkawinan adalah sah, apabila dilakukan menurut hukum Islam sesuai dengan pasal 2 ayat (1) Undag-Undang No. 1 Tahun 1974 tentang Perkawinan. ${ }^{5}$

\section{Pengertian Perceraian}

Dalam kasus perceraian yang ada di masyarakat atau dikenal dengan istilah talak, secara etimologis artinya membuka ikatan,

5 Zaeni Asyahadie, Pengantar Hukum Indonesia (Jakarta: PT. Raja Grafindo Persada, 2015), 247. 
melepaskannya dan menceraikan. Secara terminologis, menurut Abdurrahman Al-Jaziri, talak adalah melepaskan ikatan (hall al-qaid) atau bisa juga disebut mengurangi pelepasan ikatan dengan menggunakan kata-kata yang telah ditentukan. Menurut Sayid Sabiq, talak adalah melepaskan ikatan perkawianan dan mengakhiri hubungan suami istri. 6

Pengertian Hakam

Hakam adalah seorang utusan atau delegasi dari suami istri, yang dilibatkan dalam penyelesaian sengketa antar keduanya. Tetapi dalam kondisi tertentu majelis hakim dapat mengangkat Hakam yang bukan dari pihak keluarga para pihak, diantaranya yang berasal dari Hakim Mediator yang sudah ditetapkan oleh Lembaga Tahkim.7

Pengertian Mediasi

Mediasi merupakan cara penyelesaian sengketa secara damai yang tepat, efektif, dan dapat membuka akses yang lebih luas kepada para pihak untuk memperoleh penyelesaian yang memuaskan serta berkeadilan.

\section{Prinsip Mempersulit Perceraian}

Perceraian merupakan suatu perbuatan yang tidak disukai. Oleh karena itu, ia dibenci oleh Allah. Sedapat mungkin kekejaman ini harus dihindari dengan sekuat tenaga, baik dari pihak suami atau pihak istri. Juga dari pihak kaum keluarga dan mereka yang sanggup ikut serta dalam hal ini.

Dijelaskan oleh Abdul Rahman sebagai berikut: "Syari'at bermaksud membentuk suatu unit keluarga yang sejahtera melalui perkawinan, namun kalau karena beberapa alasan, tujuan ini gagal, tak perlu lagi memperpanjang harapan-harapan tesebut, sebagaimana yang diperaktikan dan diajarkan oleh beberapa agama lain bahwa perceraian itu tidak diperbolehkan. Islam lebih menganjurkan perdamaian diantara kedua suami istri daripada memutuskannya.

6 Mardani, Hukum Keluarga Islam Di Indonesia, Edisi pertama (Jakarta: Kencana, 2016), 145.

7 Muhammad Saifullah, Mediasi Dalam Tinjauan Hukum Islam Dan Hukum Positif Di Indonesia (Semarang: Walisongo Press, 2009), 12. 
Namun, jika hubungan baik diantara pasangan itu tak memungkinkan untuk terus dilangsungkan, Islam pun tidak membelenggu dengan suatu rantai yang memuakkan dan mengakibatkan keadaaan yang menyiksa dan menyakitkan. Oleh karena itu perceraian diizinkan."8

Sesuai dengan tujuan perkawinan sebagaimana disebut dimuka, yaitu membentuk keluarga bahagia dan kekal. UndangUndang Perkawinan menganut prinsip mempersulit terjadinya perceraian. Untuk bercerai harus ada alasan-alasan tertentu dan harus pula dilakukan menurut cara-cara seperti yang diatur dalam UndangUndang. Menurut Undang-Undang Perkawinan 1974, perceraian merupakan salah satu sebab putusnya perkawinan, Selain dari itu perkawinan dapat juga putus karena kematian dan atas putusan pengadilan. Perceraian hanya memungkinkan apabila tidak ada jalan lagi untuk mendamaikan pasangan suami istri, atau dengan kata lain perceraian merupakan alternatif terakhir apabila sudah tidak dapat dipertahankan.

Undang-Undang Perkawinan 1974 menetapkan, suatu perceraian hanya dapat dilakukan di depan sidang pengadilan agama, setelah pengadilan yang bersangkutan berusaha dan tidak berhasil mendamaikan pasangan suami istri tersebut (Pasal 39 (1)). Usaha untuk mendamaikan ini dapat dilakukan oleh Badan Penasehat Perkawinan dan Penyelesaian Perceraian (BP4) setempat, dengan jalan menasehati pasangan suami istri itu agar hidup rukun lagi dalam berumah tangga. ${ }^{9}$

\section{Dasar Hukum Mediasi dalam Islam}

Penyelesaian sengketa melalui cara mediasi telah lama dikenal dalam praktik hukum Islam. Mediasi merupakan istilah baru yang di dalam hukum Islam disebut dengan tahkim. Tahkim berasal dari bahasa Arab yang berarti menyerahkan putusan pada seseorang dan menerima putusan itu. ${ }^{10}$

\footnotetext{
8 Dedi Supriyadi, Sejarah Hukum Islam: Dari Kawasan Jazirah Arab Sampai Indonesia, Cet. 1 (Bandung: Pustaka Setia, 2007), 381.

9 Taufiqurrohman Syahuri, Legilasi Hukum Perkawinan Di Indonesia, Edisi pertama (Rawamangun, Jakarta: Kencana, 2013), 178.

${ }^{10}$ Hasbi Ash-Shiddieqy, Peradilan Dan Hukum Islam (Yogyakarta: PT. Al-Maarif, 1964), 69.
} 
Selain itu tahkim juga digunakan sebagai istilah bagi orang atau kelompok yang ditunjuk untuk mendamaikan sengketa yang terjadi diantara dua pihak. Dalam istilah lain dapat dinyatakan bahwa Tahkim dimaksudkan sebagai upaya untuk menyelesaikan sengketa di mana para pihak yang terlibat dalam sengketa diberi kebebasan untuk memilih seorang hakam (mediator) sebagai penengah atau orang yang di anggap netral yang mampu mendamaikan ke dua belah pihak yang bersengketa.

Bila diantara kedua suami istri timbul perbedaan yang akan membahayakan keutuhan kekeluargaan mereka, hendaklah ditunjuk penengah guna mempertemukan atau menghilangkan perbedaanperbedaan tersebut dan mendamaikan mereka. Sebagaiman firman Allah dalam surat An-Nisa' ayat 35:

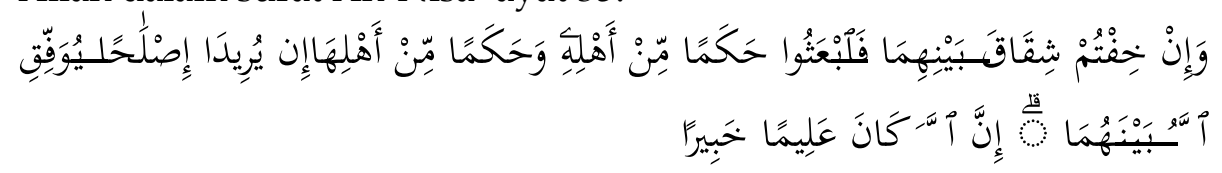

"Dan jika kamu khawatirkan ada persengketaan antara keduanya, maka kirimlah seorang hakam dari keluarga laki-laki dan seorang hakam dari keluarga perempuan. Jika kedua orang hakam itu bermaksud mengadakan perbaikan, niscaya Allah memberi taufik kepada suami-istri itu. Sesungguhnya Allah Maha Mengetahui lagi Maha Mengenal". ${ }^{11}$

Selanjutnya apabila para penengah itu gagal mendamaikan kedua suami-istri, barulah Al-Quran memperkenankan pasangan tersebut untuk berpisah. Hal ini dijelaskan dalam Al-Quran surat AnNisa' ayat 130:

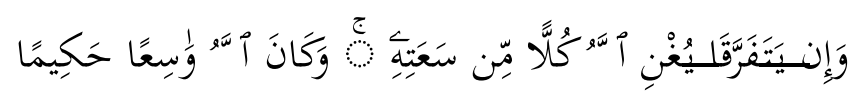

"Jika keduanya bercerai, maka Allah akan memberi kecukupan kepada masing-masing dari limpahan karunia-Nya. Dan adalah Allah Maha Luas (karunia-Nya) lagi Maha Bijaksana".

Dalam penyelesaian sengketa, Rasulullah SAW menganjurkan langkah pertama yang ditempuh adalah jalan damai, seperti disebutkan dalam sebuah hadist yang diriwayatkan oleh al-Tirmidzi:

11 Supriyadi, Sejarah Hukum Islam, 382. 
Efektivitas Mediasi dalam Penyelesaian Perkara Perceraian di Pengadilan Agama Menurut Peraturan Mahkamah Agung (PERMA) No. 1 Tahun 2016

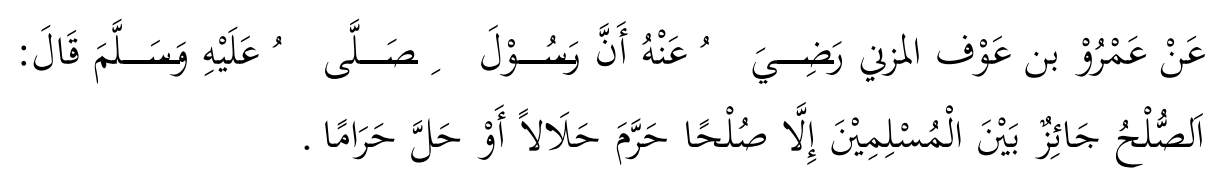

"Dari Amar bin 'Auf Al-Muzanni ra. Bahwasanya Rasulullah SAW telah bersabda: Perdamaian adalah boleh antara kaum muslimin kecuali perdamaian yang mengharamkan yang halal dan menghalalkan yang haram".

\section{Dasar Hukum Penyelesaian Sengketa di Pengadilan (Court Connected Mediation).}

Di Indonesia mediasi/perdamaian yang bersifat wajib sampai saat ini hanya diberlakukan untuk sengketa-sengketa perdata yang diajukan ke Pengadilan Negeri/Agama. Penggunaan prosedur mediasi wajib ini, dimungkinkan karena hukum acara perdata yang berlaku di Indonesia, HIR dan RBG Menyediakan dasar hukum yang kuat. Pasal 130 HIR dan Pasal 154 RBG menyatakan bahwa hakim diwajibkan untuk terlebih dahulu mengupayakan proses perdamaian, namun caranya belum diatur, sehingga ada kekosongan yang perlu diatur oleh Mahkamah Agung untuk kelancaran jalannya peradilan.

Oleh sebab itu dan untuk lebih mengoptimalkan penggunaan pasal tersebut, dikeluarkan SEMA No. 1 tahun 2002 yang mewajibkan semua majelis hakim menyidangkan perkara, dengan sungguhsungguh mengusahakan perdamaian dengan menerapkan ketentuan pasal 130 HIR/154 RBG, tidak hanya sekedar formalitas menganjurkan perdamaian. ${ }^{12}$

\section{Profesionalisme Mediator Hakim}

Proses mediasi di pengadilan dilakukan oleh seorang mediator yang berasal dari unsur hakim dan non hakim. Seseorang yang menjalankan fungsi sebagai mediator harus memiliki sertifikat yang diperoleh setelah mengikuti Pendidikan Khusus Profesi Mediator (PKPM) yang diselenggarakan oleh lembaga yang terakreditasi oleh Mahkamah Agung. Namun jika dalam wilayah pengadilan tidak ada hakim yang bersertifikat, maka hakim di lingkungan pengadilan tersebut dapat menjalankan fungsi sebagai mediator. Dengan

12 Hery Diansyah, "Efektivitas Mediasi Berdasarkan PERMA No 1 Tahun 2008 (Studi Kasus Pada Mahkamah Syari'a Banda Aceh)," Samarah Vol 1, no. 1 (June 2017): 212. 
demikian maka bagi hakim yang tidak/belum bersertifikat pun dapat menjalankan fungsi mediator.

Pada teknis pelaksanaannya, hampir semua hakim di Pengadilan Agama bertindak sebagai mediator karena Ketua Pengadilan harus menunjuk dan mencantumkan nama-nama mediator sekurang-kurangnya 5 (lima) mediator. Hal ini dimaksudkan agar semua hakim secara bergantian dapat berfungsi sebagai mediator untuk proses mediasi, disamping melaksanakan tugas utama sebagai hakim untuk proses litigasi. Tujuan lain pencantuman semua hakim ini adalah untuk memudahkan para pihak yang berperkara memilihnya sebagai mediator untuk penyelesaian perkaranya. ${ }^{13}$

\section{Langkah- langkah Mediasi dalam Pengadilan Agama}

Terdapat dua tahap dalam Mediasi yang biasanya dilakukan dalam Pengadilan; yang pertama mediasi awal litigasi, yakni mediasi yang dilaksanakan sebelum pokok sengketa diperiksa, yang kedua mediasi selama litigasi, yakni mediasi yang dilaksanakan ketika pokok sengketa dalam tahap pemeriksaan. Mediasi ini terbagi dua: pertama selama dalam pemeriksaan tingkat Pertama, dan selama pemeriksaan tingkat Banding, dan Kasasi. Kedua di luar litigasi, yaitu mediasi yang dilaksanakan di luar pengadilan, kemudian perdamaian yang terjadi dimohonkan ke Pengadilan untuk dikuatkan dalam akta perdamaian. ${ }^{14}$

Langkah selanjutnya adalah Sidang Pra Mediasi, yang perlu diperhatikan dalam hal ini; Langkah pertama: pada hari dan tanggal persidangan yang telah ditentukan dan dihadiri kedua belah pihak, majelis hakim menjelaskan tentang keharusan para pihak untuk menempuh proses mediasi serta menjelaskan prosedur mediasi menurut PERMA RI No.1 tahun 2008.

Langkah Kedua: ketua Majelis memberikan kesempatan kepada para pihak untuk memilih mediator yang dikehendaki bersama dan berunding tentang pembebanan biaya yang timbul jika memilih mediator bukan hakim. Untuk itu, majelis hakim menskors persidangan dengan cara; para pihak dengan dibantu panitera sidang,

13 Muhammad Saifullah, "Efektivitas Mediasi Dalam Penyelesaian Perkara Perceraian Di Pengadialan Agama Jawa Tengah," Al-Ahkam vol 25, no. 2 (Oktober 2015): 187-88.

${ }^{14}$ Musawwamah, "Mediasi Integratif Di Pengadilan Agama Pamekasan," Nuansa Vol 11, no. 2 (July 2014): 351. 
memilih salah satu atau dua mediator yang tertera di dalam daftar Mediator, hakim yang memeriksa perkara tidak boleh ditunjuk sebagai mediator kecuali dalam hal tidak terdapat mediator lain, jika belum berhasil, para pihak hanya dapat meminta penundaan persidangan paling lama 2 (dua) hari kerja.

Langkah Ketiga: setelah mendapat laporan dari panitera sidang, ketua majelis kemudian mencabut skors dan melanjutkan persidangan; Dalam hal para pihak telah menentukan pilihan, ketua majelis membuat Surat Penunjukan Mediator, sidang ditunda untuk proses mediasi, dalam hal para pihak menyatakan gagal memilih mediator yang dikehendaki, ketua majelis menunjuk mediator dengan membuat Surat Penunjukan Mediator, sidang ditunda untuk proses mediasi, menunda persidangan paling lama 2 (dua) hari kerja, dalam hal proses pemilihan mediator belum selesai. ${ }^{15}$

Langkah Keempat: dalam hal mediator sudah ditunjuk, selanjutnya majelis hakim melakukan langkah-langkah berikut ini; Memberitahukan mediator yang ditunjuk melalui panitera sidang, dengan menyerahkan Surat Penunjukan Mediator disertai salinan gugatan/permohonan/perlawanan, memerintahkan para pihak untuk menemui mediator yang ditunjuk guna memusyawarahkan jadwal mediasi;

Langkah kelima: paling lambat satu hari kerja berikutnya, mediator yang ditunjuk wajib menentukan hari pelaksanaan mediasi dalam sebuah Penetapan, dengan ketentuan tenggang waktu antara Surat Penunjukan Mediator dengan hari pelaksanaan mediasi tidak boleh lebih dari 7 hari kerja dengan ketentuan; Panggilan para pihak untuk mediasi dapat dilakukan oleh Jurusita dan pengganti dan biayanya dibebankan kepada panjar biaya perkara;

Langkah Keenam: sebelum melaksanakan mediasi, mediator wajib melakukan beberapa ketentuan, diantarnaya; Mempelajari gugatan/permohonan sehingga diperoleh suatu gambaran awal tentang pokok permasalahan, mempersiapkan usulan jadwal pertemuan mediasi yang akan dibahas dan disepakati.

15 Musawwamah, 352. 
Adapun perubahan signifikan yang dapat masyarakat rasakan dari PERMA No. 1 Tahun 2008 menjadi PERMA No. 1 Tahun 2016, di antaranya adalah: 16

Pertama, Terkait batas waktu mediasi yang lebih singkat dari 40 (empat puluh) hari menjadi 30 hari terhitung sejak penetapan perintah melakukan Mediasi.

Kedua, Dalam PERMA Nomor 1 Tahun 2016 mengenal kesepakatan sebagian pihak (partial settlement) yang terlibat dalam sengketa atau kesepakatan sebagian objek sengketanya. Hal ini berbeda dengan PERMA Nomor 1 Tahun 2008, di mana apabila hanya sebagian pihak yang bersepakat atau tidak hadir, maka mediasi dianggap dead lock (gagal).

Ketiga, Pengaturan masalah kewajiban para pihak menghadiri pertemuan mediasi dengan atau tanpa kuasa hukum, kecuali ada alasan sah seperti kondisi kesehatan yang tidak memungkinkan hadir dalam pertemuan mediasi berdasarkan surat keterangan dokter; di bawah pengampuan; mempunyai tempat tinggal, kediaman atau kedudukan di luar negeri; atau menjalankan tugas negara, tuntutan profesi atau pekerjaan yang tidak dapat ditinggalkan.

Keempat, PERMA Nomor 1 Tahun 2016 menegaskan kembali peranan Mediator Independen untuk berperan lebih aktif dalam menyelesaikan perkara atau sengketa di luar pengadilan, yang kemudian hasil mediasi yang disepakati dapat diajukan penetapan ke Pengadilan melalui mekanisme gugatan.

Berhubungan dengan masalah pengaturan iktikad baik dan akibat hukum para pihak yang tidak beriktikad baik dalam proses mediasi, dalam PERMA Nomor 1 Tahun 2008 penjabarannya tidak rinci seperti di dalam PERMA Nomor 1 Tahun 2016. ${ }^{17}$

\section{Efektivitas PERMA No. 1 Tahun 2016}

Menurut Ahmad Ali, pada umumnya yang mempengaruhi efektivitas suatu peraturan perundang-undangan adalah profesional dan optimal pelaksanaan, peran, wewenang, dan fungsi dari penegak

16 Lilik Andaryuni, "Efektivitas PERMA No 1 Tahun 2016 Tentang Prosedur Mediasi Di Pengadilan Dalam Menekan Angka Cerai Di Pengadilan Agama," Fenomena Vol 10, no. 2 (2018): 100.

17 Andaryuni, 100. 
hukum baik di dalam menjalankan tugas yang dibebankan terhadap diri mereka/ dalam penegakan aturan tersebut.

Efektivitas hukum dapat diartikan sebagai kajian kaidah hukum yang harus memenuhi syarat, yaitu hukum berlaku secara Yuridis, Sosiologis dan Flosofis. Menurut Soerjono Sokanto, hukum dikatakan efektif tergantung faktor-faktor yang melibatkan di dalamnya: Faktor hukum (undang-undang), faktor penegak hukum, faktor sarana yang mendukung penegakan hukum, warga masyarakat dalam lingkup aturan tersebut, dan kebudayaan.18

Berdasar teori Soerjono Sokanto, efektif tidaknya proses mediasi dapat dilihat dari lima hal berikut: Berdasarkan faktor hukum (aturan), aturan hukum terkait mediasi sudah cukup jelas dan rinci diatur dalam PERMA No. 1 Tahun 2016, dan lebih fleksibel dibandingkan PERMA No. 1 Tahun 2008 tentang prosedur mediasi di Pengadilan Agama. Adanya payung hukum yang mengatur tentang mediasi ini menegaskan bahwa secara filosofis dasar acuan pelaksanaan mediasi di Pengadilan Agama sudah cukup kuat. Faktor Mediator, mediator sebagai salah satu pelaksana PERMA No. 1 Tahun 2016, mempunyai peran yang signifikan dalam proses mediasi, sehingga harus memiliki ketrampilan dan keahlian khusus, sebagaimana amanat Pasal 13 PERMA No. 1 Tahun 2016 bahwa,

"Setiap Mediator wajib memiliki Sertifikat Mediator yang diperoleh setelah mengikuti dan dinyatakan lulus dalam pelatihan sertifikasi Mediator yang diselenggarakan oleh Mahkamah Agung atau lembaga yang telah memperoleh akreditasi dari Mahkamah Agung. ${ }^{19}$

Lebih lanjut dalam Pasal 1 ayat (2), bahwa Mediator adalah Hakim atau pihak lain yang memiliki Sertfikat Mediator sebagai pihak netral yang membantu para pihak dalam proses perundingan guna mencari berbagai kemungkinan penyelesaian sengketa tanpa menggunakan cara memutus atau memaksakan sebuah penyelesaian. Dengan demikian, maka bagi hakim yang tidak/ belum bersertifikat pun dapat menjalankan fungsi mediator.

18 Soerjono Sukanto, Faktor-Faktor Yang Mempengaruhi Penegakan Hukum (Jakarta: Raja Grafindo Persada, 2008), 8.

${ }^{19}$ Pasal 13 ayat (1) PERMA No. 1 Tahun 2016 
Rumusan Pasal 1 ayat (2) dan Pasal 13 PERMA No. 1 Tahun 2016 di atas terlihat, ada dua jenis mediator, yakni mediator yang memiliki sertifikat setelah memiliki pendidikan mediasi, baik berasal dari hakim maupun non hakim, dan kedua hakim yang tidak memiliki sertifikat mediator tapi diangkat menjadi mediator karena kekungan atau tidak memiliki hakim yang bersertifikat mediator. ${ }^{20}$

\section{Faktor- Faktor Penghambat Efektivitas Mediasi dalam Pengadilan}

Pelaksanaan mediasi dalam Pengadilan telah dilakukan dengan upaya-upaya maksimal untuk mencapai sebuah keberhasilan mediasi, namun terdapat beberapa hambatan yang dihadapi oleh pihak mediator terutama dari pihak yang bersengketa. Adapun faktorfaktor yang menjadi hambatan dalam keberhasilan mediasi diantaranya:21 Pertama, kehadiran para pihak yang berperkara sangatlah penting dalam pelaksanaan mediasi, seringkali para pihak menunda-nunda atau tidak hadir pada saat proses mediasi walaupun mereka telah dipanggil secara patut dan berturut-turut.

Kedua, pengetahuan para pihak tentang proses mediasi. Tidak pahamnya para pihak tentang proses mediasi, para pihak menganggap mediasi hanyalah sebuah prosedur ataupun tata cara dalam menjalankan proses persidangan, para pihak mengikuti proses mediasi bukan karena keinginan hati, karena pada dasarnya upaya-upaya damai telah mereka lakukan sebelum perkara dibawa ke pengadilan. Para pihak hanya mengikuti mediasi karena kekhawatiran putusan mereka akan batal demi hukum apabila tidak mengikuti proses mediasi.

Ketiga, kurangnya i'tikad baik dari para pihak. Mediasi melibatkan orang-orang yang mempuyai watak dan sifat yang berbeda-beda, banyak diantara para pihak yang merasa terpaksa menjalani proses mediasi hanya karena prosedur yang telah ditetapkan oleh pengadilan. Pihak yang merasa terpaksa menjalani prosedur mediasi ini menunjukan sikap sepele atau menganggap remeh proses mediasi tersebut.

${ }^{20}$ Andaryuni, "Efektivitas PERMA No. 1 Tahun 2016 Tentang Prosedur Mediasi Di Pengadilan Dalam Menekan Angka Cerai Di Pengadilan Agama," 109.

${ }^{21}$ Diansyah, "Efektivitas Mediasi Berdasarkan PERMA No 1 Tahun 2008 (Studi Kasus Pada Mahkamah Syari'ah Banda Aceh)," 221. 
Keempat, adanya pihak ketiga. Adanya pihak ketiga yang bisa timbul dari manapun, bisa saja pihak advokat yang tidak memberi dukungan dalam menjalankan proses mediasi, selain itu ada juga pihak luar yang memperkeruh suasana mediasi, karena pihak tersebut ingin mengeruk keuntungan dari sengketa tersebut.

Kelima, dilihat dari tingkat kerumitan perkara yang tidak bisa dilesaikan dengan cara mediasi walaupun sudah diusahakan beberapa upaya untuk mendamaikan kedua belah pihak.

Karena adanya beberapa hambatan yang menghalangi pelaksanaan mediasi, hakim mediator mempunyai beberapa cara tertentu untuk menanganinya yaitu :22

Dalam berkomunikasi, mediator harus berbicara dengan tenang serta meyakinkan para pihak bahwa berdamai adalah cara yang dapat diusahakan. elanjtnya Mediator harus bersikap empati, yaitu memperlihatkan rasa pengertian dan tanpa memperlihatkan keberpihakan kepada salah satu klien.

Mediator menghindari berbincang-bincang dengan salah satu pihak sebelum atau pada waktu kedatangan pihak lain, bila hal ini terjadi dapat menimbulkan kesenjangan antara para pihak. Dibutuhkan pernyataan humor dari mediator perlu untuk merefleksikan suasana perundingan, tetapi tidak menjadiakan salah satu pihak sebagai bahan humor atau hal-hal sensitif bagi para pihak. Terakhir dalam mengatasi emosi yang tinggi dari para pihak, mediator memberikan waktu istirahat sejenak. Setelah itu dalam perundingan mediator harus selalu mengingatkan bahwa para pihaklah yang mencari penyelesaian terbaik bukan mediator.

\section{Penutup}

Mediasi perkara perceraian di Pengadilan Agama secara umum belum efektif karena belum sesuai dengan maksud diterbitkannya Peraturan Mahkamah Agung tentang Prosedur Mediasi di pengadilan. Belum efektifnya mediasi ini disebabkan karena pelaksana mediasi belum sepenuhnya (secara maksimal) melakukan mediasi dan masih terkesan hanya memenuhi formalitas, standar ukuran keberhasilan mediasi perkara perceraian yang sulit dicapai, dan budaya masyarakat dalam merespon upaya damai di pengadilan. Agar mediasi dapat

22 Diansyah, 222. 
efektif maka perbaikan dan perubahan yang meliputi pelaksana mediasi, aturannya dan budaya masyarakat harus dilakukan dan berjalan seiring dan saling mendukung.

\section{Daftar Pustaka}

Andaryuni, Lilik. "Efektivitas PERMA No 1 Tahun 2016 Tentang Prosedur Mediasi Di Pengadilan Dalam Menekan Angka Cerai Di Pengadilan Agama." Fenomena Vol 10, no. 2 (2018).

Ash-Shiddieqy, Hasbi. Peradilan Dan Hukum Islam. Yogyakarta: PT AlMaarif, 1964.

Asyahadie, Zaeni. Pengantar Hukum Indonesia. Jakarta: PT RajaGrafindo Persada, 2015.

Diansyah, Hery. "Efektivitas Mediasi Berdasarkan PERMA No 1 Tahun 2008 (Studi Kasus Pada Mahkamah Syari'ah Banda Aceh)." Samarah Vol 1, no. 1 (June 2017).

Kereh, Hanasthasia Karrenina. "Penyelesaian Sengketa Melalui Mediasi Di Pengadilan Menurut PERMA No 1 Tahun 2016 Tentang Prosedur Mediasi." Lex Administratum Vol 7, no. 2 (June 2019).

Mardani. Hukum Keluarga Islam Di Indonesia. Edisi pertama. Jakarta: Kencana, 2016.

Musawwamah. "Mediasi Integratif Di Pengadilan Agama Pamekasan." Nuansa Vol 11, no. 2 (July 2014).

Saifullah, Muhammad. "Efektivitas Mediasi Dalam Penyelesaian Perkara Perceraian Di Pengadialan Agama Jawa Tenah." AlAhkam vol 25, no. 2 (Oktober 2015).

- - - Mediasi Dalam Tinjauan Hukum Islam Dan Hukum Positif Di Indonesia. Semarang: Walisongo Press, 2009.

Sukanto, Soerjono. Fakto-Faktor Yang Mempengaruhi Penegakan Hukum. Jakarta: Raja Grafindo Persada, 2008.

Supriyadi, Dedi. Sejarah Hukum Islam: Dari Kawasan Jazirah Arab Sampai Indonesia. Cet. 1. Bandung: Pustaka Setia, 2007.

Syahuri, Taufiqurrohman. Legilasi Hukum Perkawinan Di Indonesia. Edisi pertama. Rawamangun, Jakarta: Kencana, 2013.

Yusdani. Menuju Fiqih Keluarga Progresif. Yogyakarta: Kaukaba Dipantaran, 2015. 
Efektivitas Mediasi dalam Penyelesaian Perkara Perceraian di Pengadilan Agama Menurut Peraturan Mahkamah Agung (PERMA) No. 1 Tahun 2016

http;//databoks.katadata.co.id/datapublish/2020/02/20/ramai-RUUketahanan-keluarga-berapa-angka-perceraian-di-Indonesia. (diakses 3 Maret 2020).

http://www,pa-malangkota,go.id//Angka-keberhasilan-Mediasi-Pa-MalangTahun-2018 (diakses 3 Maret 2020). 